J. Clin. Chem. Clin. Biochem.

Vol. 24, 1986, pp. 529-532

(C) 1986 Walter de Gruyter \& Co. Berlin - New York

\title{
Urinary Glutathione-S-Transferase in Cisplatin Nephrotoxicity in the Rat
}

\author{
By D. A. Feinfeld, V. L. Fuh
}

Department of Medicine, Harlem Hospital Center, Columbia University College of Physicians \& Surgeons, New York, New York, U.S.A. and

\section{R. Safirstein}

Department of Medicine, Mount Sinai School of Medicine, New York, New York, U.S.A.

(Received January 6/April 2, 1986)

Summary: Rats given a single toxic dose of cisplatin all developed detectable glutathione-S-transferase activity in their urine between the third and fifth day after injection of cisplatin, simultaneously with the decreased urine osmolality and increased urine volume characteristic of cisplatin nephrotoxicity. Peak urinary glutathione-S-transferase levels occurred at the same time as maximal serum creatinine levels, and there was a significant statistical correlation between these two variables. These findings suggest that urinary glutathione-S-transferase activity is a marker for proximal renal tubular injury from cisplatin.

\section{Nephrotoxizität von Cisplatin bei der Ratte: Ausscheidung von Glutathion-S-transferase im Harn}

Zusammenfassüng: Ratten erhielten eine toxische Einzeldosis von Cisplatin. Alle Tiere entwickelten zwischen dem dritten und dem fünften Tag nach Injektion von Cisplatin eine nachweisbare katalytische Aktivität von Glutathion-S-transferase im Harn. Zugleich trat die für die Nephrotoxizität von Cisplatin charakteristische Zunahme des Harnvolumens und Abnahme der Osmolalität des Harns auf. Die höchste katalytische Aktivität von Glutathion-S-transferase im Harn fand sich gleichzeitig mit der höchsten Konzentration von Kreatinin im Serum. Es bestand eine signifikante statistische Korrelation zwischen diesen beiden Variablen. Unsere Ergebnisse weisen darauf hin, $\mathrm{daB}$ die katalytische Aktivität von Glutathion-S-transferase im Harn ein Merkmal für eine Schädigung des proximalen Nierentubulus durch Cisplatin ist.

\section{Introduction}

Cisplatin is a widely used antineoplastic drug whose major toxic effect is on the kidney. The drug causes necrosis of proximal tubular cells both in patients $(1$, 2) and experimental animals $(3,4)$. This lesion is frequently associated with renal failure, which is partially ameliorated by pretreatment with intravenous fluids and osmotic diuretics (5).

Previous studies using other nephrotoxic substances, such as heavy metals (6) and gentamicin (7), have shown that the appearance of glutathione-S-transferase B (ligandin) in the urine is a good marker for proximal tubular injury. This enzyme is abundant in the cytosol of proximal renal tubular cells, as well as in hepatocytes and small intestinal mucosa (8). In addition to being a general binding protein for organic anions, steroids, and carcinogens (9), it catalyzes the conjugation of certain ligands to the sulfhydryl group of reduced glutathione (10). Glutathione$S$-transferase is not found in the urine of normal animals or humans $(6,7,11)$. In this study we measured urine glutathione-S-transferase during experimental cisplatin nephrotoxicity, as we felt that this substance might indicate tubular damage, as it does in other models. 


\section{Materials and Methods}

All studies were performed on male Sprague-Dawley rats weighing $200-300 \mathrm{~g}$. Eight animals were placed in metal metabolic cages that separated urine from feces and were given $20 \mathrm{~g}$ of food (Charles River Mouse and Hamster formula chow) and $100 \mathrm{ml}$ of tap water daily. After the rats consistently ate all their food and established a constant drinking pattern (a period usually lasting $5-7$ days), cisplatin, $5 \mathrm{mg} / \mathrm{kg}$ ( $1 \mathrm{~g} / 1$ in 154 $\mathrm{mmol} / \mathrm{l} \mathrm{NaCl}$ ), was administered intraperitoneally. The consumption of food and water and the excretion of urine, collected under oil in plastic graduated cylinders, was determined daily, beginning one day prior to cisplatin injection, so that each rat served as its own control. Blood for creatinine determination was drawn into heparinized tuberculin syringes by cardiac puncture on the day of cisplatin administration and on the fourth and seventh day thereafter.

Urine osmolality was measured by a vapor pressure osmometer (Wescor, Inc., Logan UT, USA, Model 5100 C). Plasma creatinine was determined by kinetic analysis of the chromogen formed by creatinine upon reaction with picric acid (Technicon Autoanalyzer).

Glutathione-S-transferase activity was determined quantitatively by measuring the rate of enzyme-catalyzed conjugation of reduced glutathione with 1-chloro-2,4-dinitrobenzene (7). Two hundred microliters of urine was added to $2.5 \mathrm{ml}$ of a test solution containing $1 \mathrm{mmol} / 1$ 1-chloro-2,4-dinitrobenzene and $1 \mathrm{mmol} / \mathrm{l}$ reduced glutathione (both from Sigma Chemical Co., St. Louis, MO, USA) in $0.1 \mathrm{~mol} / \mathrm{l}$ potassium phosphate buffer at $\mathrm{pH}$ 6.5. Enzyme activity was measured as a function of absorbance at a wavelength of $344 \mathrm{~nm}$ in a Spectronic $2000^{\circledR}$ dual beam recording spectrophotometer (Bausch \& Lomb, Rochester, NY, USA). A control solution containing all reagents without the urine was run simultaneously to allow the automatic subtraction of noncatalyzed conjugation. Activity was expressed as micromol of glutathionedinitrobenzene conjugate per minute. Twenty-four-hour urine gluthatione-S-transferase excretion was determined by multiplying the value obtained from each aliquot by 5 and then by the urine volume in ml.

The excretion of cisplatin in the urine of rats is inconsequential by 24 hours following injection of the drug $(12,13)$. However, to rule out any effect of urinary cisplatin on the enzymatic reaction, the reaction was measured on a solution containing $1.1 \mathrm{mmol} / 1$ cisplatin, $1 \mathrm{mmol} / 1$ glutathione and $1 \mathrm{mmol} / 1$ 1-chloro-2,4-dinitrobenzene in the buffer, and a standard quantity of glutathione-S-transferase. This was compared with the reaction of an identical solution without the cisplatin.

Serial results were compared statistically with the baseline using Student's t-test for paired data. Linear regression was determined by the method of least squares.

\section{Results}

Each of the rats developed a substantial decrease in renal function by the fourth day after injection of cisplatin, as documented by a $60-267 \%$ increase in plasma creatinine above pre-injection levels. The mean control creatinine level was $33 \pm 3 \mu \mathrm{mol} / \mathrm{l}(0.38$ $\pm 0.03 \mathrm{mg} / \mathrm{dl}) ;$ by day 4 this had risen to $81 \pm 6$ $\mu \mathrm{mol} / 1(0.91 \pm 0.07 \mathrm{mg} / \mathrm{dl})$. As noted in figure 1 , there was a concomitant fall in urine osmolality. Urine volume was increased by day 4 .

Urinary glutathione-S-transferase was undetectable in all rats at the beginning of the study but began to

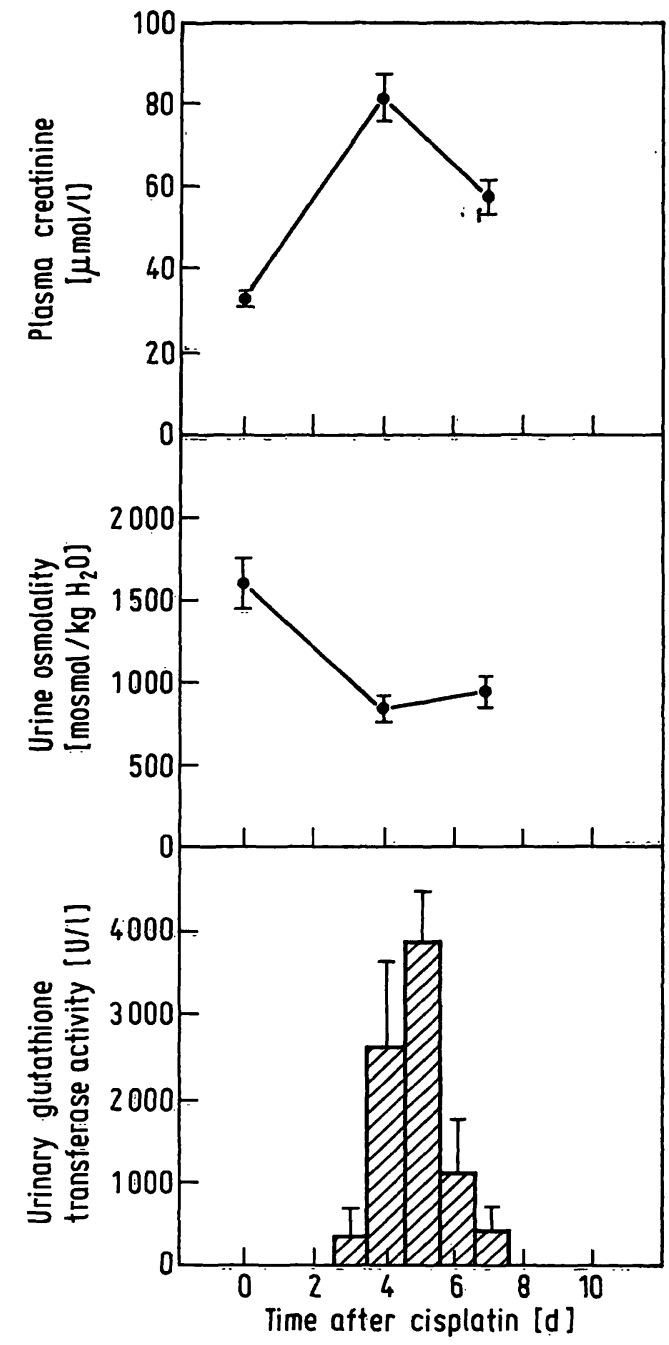

Fig. 1. Plasma creatinine concentration, urine osmolality, and urine glutathione-S-transferase activity in rats given an injection of cisplatin at the beginning of day 1 .

appear after the third day post injection of cisplatin (tab. 1). By the fifth day, all animals had detectable glutathione-S-transferase in their urine, with a mean of $0.77 \pm 0.11 \mathrm{nmol} / \mathrm{min} \cdot 200 \mu \mathrm{l}$ aliquot.

The enzymuria decreased during the sixth and seventh days: all of the rats had absent or markedly lower urinary glutathione-S-transferase levels during the final 24-hour collection period. The peak enzymuria preceded by $1-2$ days the nadir of urine osmolality and maximum urine volume (fig. 1).

Twenty-four-hour urinary glutathione-S-transferase excretion rose from zero in all animals to become maximal between the fourth and fifth days post cisplatin injection. This ranged from 42.3 to $246 \mathrm{nmol} /$ $\min \cdot 24 \mathrm{~h}$ at day $4-5$, with a mean of $115.8 \pm 20.7$. There was a modest correlation between maximum 24-hour urinary glutathione-S-transferase and peak plasma creatinine, with $r=0.73(p<0.05)$. Addition of $1.1 \mathrm{mmol} / 1$ cisplatin to a known solution of glutathione-S-transferase did nòt affect its enzymatic activity compared to a control. 


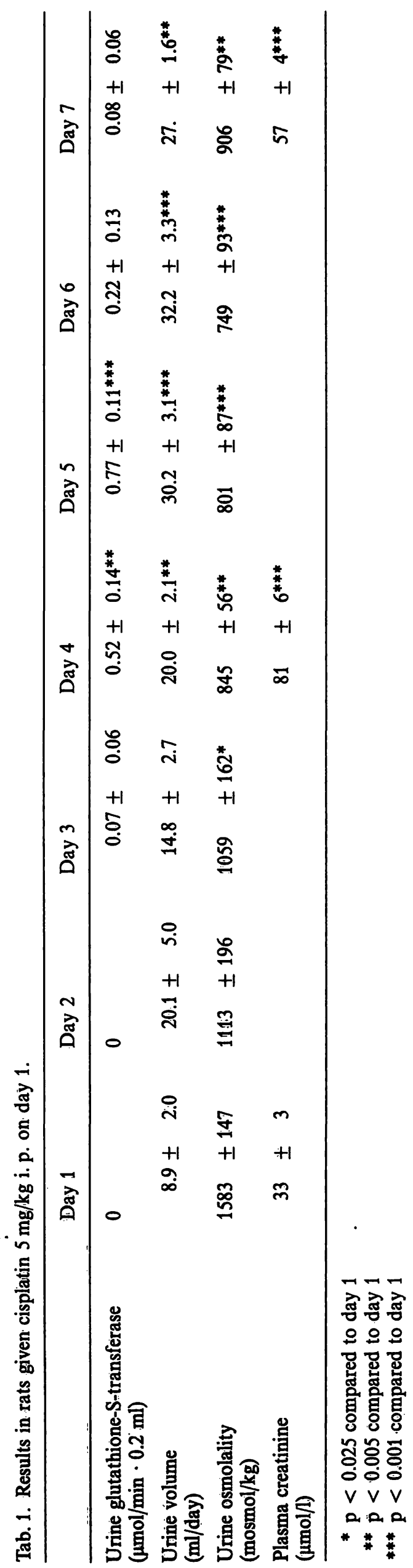

\section{Discussion}

Within four to five days following injection of a nephrotoxic dose of cisplatin, all animals in this series developed detectable levels of glutathione-S-transferase in their urine. This was associated with the previously described manifestations of cisplatin-induced acute renal failure: elevated plasma creatinine, increased urine volume and decreased urine osmolality (4). By the seventh day after injection, urinary enzyme activity was markedly diminished (tab. 1).

This pattern of urinary glutathione-S-transferase excretion is similar to that found in rats given other proximal tubular toxins: absence in the control period, appearance of enzymuria after administration of the toxin, and finally disappearance of detectable urinary glutathione-S-transferase following peak excretion (6). The period of enzymuria following cisplatin administration appears to last approximately 48 to 72 hours, as it does in mercury and dichromate toxicity $(6,11)$.

Glutathione-S-transferase is normally undetectable in urine except by radioimmunoassay for the enzymatic protein (i. e. ligandin) (14). When there is proximal tubular necrosis, the enzyme is released into the urinary space and washed into the urine (11). It might also appear in the blood at this point and could enter the urinary space via filtration, although its molecular weight $\left(M_{\mathrm{r}}=44000\right)$ might impede passage across the glomerular capillary barrier.

The morphological changes in tubular cells following a toxic dose of cisplatin occur after 72 hours $(4,15)$. In this study, glutathione-S-transferase appeared in the urine between 72 and 96 hours after cisplatin. This suggests that tubular cell disruption occurs at this time. This coincided with the disturbances in glomerular filtration rate (as determined from the rise in serum creatinine) and tubular function (as determined by low urine osmolality) (fig. 1). The correlation between peak serum creatinine and maximum urine glutathione-S-transferase excretion implies that the amount of this cytosolic protein released into the urine may reflect the degree of tubular injury.

Earlier studies of urinary glutathione-S-transferase in nephrotoxic renal injury also found enzymuria at the time of cellular injury $(6,7)$. A recent investigation of cadmium nephrotoxicity found that urinary glutathione-S-transferase becomes elevated 13 weeks after administration of the toxin: the time when cellular injury occurs (16). This confirms that urinary glutathione-S-transferase is a useful prospective marker of injury to the proximal nephron. 


\section{Acknowledgement}

This study was supported in part by grants from the U.S. Public Health Service (AM 28683) and the Ancient Egyptian Arabic Order Nobles Mystic Shrine of North and South Amer-

\section{References}

1. Lippman, A. J., Helson, C., Helson, L. \& Krakoff, I. H. (1973) Cancer Chemother. Rep. 57, 191-200.

2. Gonzalez-Vitale, J. C., Hayes, D. M., Cvitkovic, E. \& Sternberg, S. S. (1977) Cancer 30, 1362-1371.

3. Schaeppi, U., Heyman, I. A., Fleischman, R. W., Rosenkrantz, H., Ilievski, V., Phelan, R., Cooney, D. A. \& Davis, R. D. (1973) Toxicol. Appl. Pharmacol. 25, 230-241.

4. Safirstein, R., Miller, P., Dikman, S., Lyman, N. \& Shapiro, C. (1981) Amer. J. Physiol. 241, F175-F185.

5. Hayes, D. M., Cvitkovic, E., Golbey, R. B., Scheiner, E., Helson, L. \& Krakoff, I. H. (1977) Cancer 30, 1372-1381.

6. Feinfeld, D. A., Bourgoignie, J. J., Fleischner, G., Goldstein, E. J., Biempica, L. \& Arias, I. M. (1977) Kidney Int. 12, 387-392.

7. Feinfeld, D. A., Fleischner, G. M. \& Arias, I. M. (1981) Clin. Sci. 61, 123-125.

8. Fleischner, 'G. M., Robbins, J. \& Arias, I. M. (1972) J. Clin. Invest. $51,677-684$. ica and its Jurisdictions, Inc. Ms Fuh was a Summer Fellow of the Association for Women in Science Educational Foundation. We thank Ms $H$. Mortimer for assistance in completing the manuscript.

9. Fleischner, G. M., Kamisaka, K., Gatmaitan, Z. \& Arias, I. M. (1978) In: Glutathione: Metabolism and Function (Jakoby, W. B. \& Arias, I. M., eds.) Raven Press, New York, pp. 259-263.

10. Habig, W., Pabst, M., Fleischner, G., Gatmaitan, Z., Ariạs, I. M. \& Jakobỳ, W. (1974) Proc. Nat. Acâd. Sci. USA 71, $3879=3882$.

11. Feinfeld, D. A., Fleischner, G. M., Goldstein, E. J., Levine, R. D., Levine, S. D., Avram, M. M. \& Arias, I. M. (1979) Curr. Prob. Clin. Biochem. 9, $273=280$.

12. Safirstein, R., Miller, P. \& Guttenplan, J. B. (1984) Kidney Int. $25,753-758$.

13. Safirstein, R., Daye, M., Miller, P. \& Guttenplan, J. (1980) Fed. Proc. 40, 651A.

14. Bass, N. M., Kirsch, R. E., Tuff, S. A., Campbell, J. A. \& Saunders, J. S. (1979) Clin. Sci. 56, 419-426.

15. Dobyan, D. C., Levi, J., Jacobs, C., Kosek, J. \& Weiner, M. W. (1980) J. Pharm. Clin. Therap. 213, 551-556.

16. Bomhard, E., Maruhn, D., Paar, D. \& Wehling, K. (1984) Contr. Nephrol. 42, 142-147.

Donald A. Feinfeld, M.D.

Chief, Renal Division

Department of Medicine

Harlem Hospital Center

506 Lenox Avenue

New York, New York 10037

U.S.A. 